\title{
Development of Schoolchildren's Creativity in the Process of Enculturation
}

\author{
Irina M. Kyshtymova* \\ Irkutsk State University \\ 1 Karl Marx Str, Irkutsk, 664003, Russia
}

Received 04.07.2014, received in revised form 29.08.2014, accepted 05.11.2014

\begin{abstract}
This article substantiates the thesis of efficiency of enculturation for the development of schoolchildren's creativity. Key concepts of creation and creativity are outlined, their contradictions are labeled.

The paper presents an approach towards understanding and development of creativity, the base of which are representations of psycho-semiotics, cultural heritage and existential psychology. It is demonstrated that creativity constitutes a feature of an individual manifested in the implementation of personal significance by means of culture. Both components of creativity are characterized. The article reveals that the development of creativity is associated with semantic dynamics and shaping of signification skills of meaningful expression through the facilities of sign systems.

The article provides substantiation for the understanding of educational environment as a system related with culture as a basic system and an individual in terms of homomorphy. Dependence of semantic development of a schoolchild on the kind of structural components of the culture, the values of which are being carried over via educational environment, has been demonstrated.

The description of the ontologic structure of culture is given. The article shows the significance of its kernel formation - a reference culture that transmits meanings by means of precedent-setting texts. The role of the reference culture in the processes of creativity development is revealed. Cultural eclecticism, when values of different structural components of the structure are being transmitted in the educational environment is assumed to cause unpredictable developmental effects.

The paper reveals the content of "enculturation" concept and its fundamental importance for the creativity development mechanism. A psycho-semiotic model of educational environment at school dedicated to the development of creativity of schoolchildren is described.
\end{abstract}

Keywords: enculturation, creativity of schoolchildren, A psycho-semiotic model of educational environment in school.

Research area: pedagogy, psychology.

\section{Introduction}

Scientists have always been searching for the effective methods of developing creative abilities of an individual. The increased number of studies dedicated to the issue bears testimony of the awareness of the importance of creativity for personal and social productivity, on the one hand, and of the unsolved problem of understanding the creative development mechanism and contradictory nature of approaches towards it, on the other hand. Moreover, available means of developing creativity today suggest

(C) Siberian Federal University. All rights reserved

* Corresponding author E-mail address: info@creativity.ru 
implementation within the framework of local programmes [9, 22, 25, 27], which limits their educational potential. The importance of elaboration of universal methods of development of schoolchildren's creativity in the conditions of the mainstream learning process at school is due to the fact that, firstly, school educational environment is predominating in the overall developmental context, while, secondly, there is no systematic targeting of contemporary school at the development of creativity.

\section{The content of the "creativity" concept}

The problem of determining the creative development mechanism and elaboration of ways of its practical implementation is associated, primarily, with the understanding of the concept of "creation" and "creativity". In scientific literature, they are sometimes differentiated on the basis of the procedural attributes, but are often synonymous: for example, V.N. Druzhinin defines creativity as "tvorcheskost" [7]. Meanwhile, the term "creation" is chronologically primary, loaded with philosophical content and even poetized, making it difficult to use it as an operational concept. Therefore, for practical research the term "creativity" appears to be more appropriate.

In terms of the multiparadigmatic nature of psychology, multiple definitions of creativity have found theoretical substantiation, which set divergent vectors of its investigation. Scientific understanding of creation and creativity are contradictory in their fundamental substantive positions. Both narrowly operational understanding of creativity [34] and the ideas of it as a feature of the human life as a whole are substantiated. Relationships between creativity and intelligence are also understood in different ways: creativity is regarded as a component of intelligence [31], intelligence is understood as a structural component of creativity [2], their independence is asserted [23]. In the presence of the views on creativity as a constant feature, the representations of variability of creativity have gained a wider acceptance in the course of life depending on different factors. A number of concepts would assert a direct link between creativity, morality and social adaptability of creative people [2], herewith the attitudes expressing the idea of maladaptability and immorality of the "creative people" are pro-active [25]. Creativity is regarded from a quantifiedmechanistic standpoint [3], and as a transcendence, a gift, a revelation [20]. An approach towards creativity as a creative activity is pronounced [2], as well as understanding of its irreducibility to activity [23]. The specified antinomies create complications for understanding of the universal mechanisms of creativity development and elaboration of psycho-friendly developmental programmes.

Methodological principles of psychosemiotic, cultural - historical and existential approaches in psychology were laid at the bottom of the conceptual definition, which served as the basis for its operationalization and elaboration of methods for creativity development. Creativity is understood as a feature of an individual, manifested in realization of personal meaning through the culture. Distinguishing features of the expressed meaning determine substantial features of creativity, while distinguishing features of expression, singularity of character representation of the creative product trace the peculiarities of the form.

Thus, the essential components of creativity are personal meaning and signification skills involving proficiency in sign systems of meaning expression. Both concepts: personal meaning and signification skills - are operationalized, that allows to simulate methods of creativity diagnostics and programmes for its development. 
Personal meaning being the backbone feature of the personality, marks human relation to the world and himself. While multiple means may be used to transmit it into culture in the course of an act of creation, they are united by the nature of the sign, and therefore, may be construed semiotically - as a code, because "the psychology of creativity is, in fact, the psychology of creating forms referred to the subject of creation" $[1, \mathrm{p}$. 50]. Implementation of personal meaning is only possible by the "means of culture". In psychology, mediators are regarded as "the means" of expression; semiotically they are combined by the concept of sign systems that allow to apply a more rigorous approach to the analysis of their role in the processes of expression of meaning. Regularities of individual sign systems are the subject of study of scientific disciplines reflecting their peculiarities. General patterns of symbolic expression of the meaning constitute the subject of psycho-semiotic research.

A peculiarity of the "means of culture" is their consistency, the creative process is governed by logic used in the process of expression of a sign system. The level of proficiency in the "means of culture" defines the possibility of their creative use, increasing opportunities for variation combinations of the system elements.

The development of creativity as a personality trait manifested in realization of personal meaning by means of culture implies, on the one hand, the development of personal meaning, on the other hand, signification skills to express it.

\section{Enculturation as a prerequisite} for the development of creativity

Meanings develop in the process of communication. Therewith, it is important to understand, first, that productive for meaningmaking is such type of communication, which was specified by M.Buber as "I-Thou" (as opposed to communication between "I-It") and involves a dialogue. Secondly, in the context of the semiotic paradigm, communication is regarded as a semiosis - an interaction of symbolic systems, i.e. a party of the process of the meaning exchange may be not a human being only, but also a book, music - any symbolic reality (a text). Moreover, it is essential that the semantic level of the text, a person enters in semiosis with, is high - that would determine the development of the semantic system in the process of mutual assistance. Differentiation of the meaningful levels is presented in the work of Ia.A.Feldman [28] and B.S.Bratus' [4], it was the basis of isolation of diagnostic indicators of expressiveness of personal meaning in the course of diagnosis of creativity [16]. Symbolic nature of texts, as well as their differentiation on the basis of cultural significance, according to which there is a group of precedent (transmitting spiritual meanings) texts, determine the importance of turning to the concept of enculturation.

Hence, the statement about cultural predicament of creativity, about the dependence of its level on the level of human culture is not obvious in psychological concepts. Understanding of creativity as originality (non-normativity) leads to opposing of the concepts of "culture", traditionally understood as a system of standards and "creativity" as a trend to ignore the latter. Reasoning of the dependence of the level of creativity on the level of culture is requisite to understand the unproductiveness of creativity development practices based on nurturing the sense of self-exceptionalism, which are the cause of social maladaptation of "creative" people. Culture determining the vector of development of creatively free and responsible person would, at the same time, set the landmarks of spiritual life, thus reducing the likelihood of hazardous illusions about one's own significance [6]. 
Insufficient attention paid today by psychologists to culture as a component that determines special nature of human creative development, non-discriminative concepts of "social" and "cultural" as replaced by the "socio-cultural" definition, understanding of culture as a development environment (despite the fact that it is "not the environment, but the means and objective of development" [11, p. 29]) complicate the study of systematic regularities of development of a creative personality.

Enculturation is understood as the process of familiarizing of an individual with culture, learning the standards and patterns of behaviour typical of a given culture [35]; learning, in the process of development, ethical, aesthetic, moral and philosophical views inherent to the national culture, valuation and meaningful benchmarks and ways of development of creative activity [15]. Enculturation is the process of fusion with the native culture, establishment of a civilized person - a refined person, as different from socialization - the process of growing into society, evolvement of a social person [14]. Not any development is enculturation, although each is happening within the culture. Enculturation involves the assignment of a system of the most significant values of a culture.

With the nature of "universality", performing the function of "bonding", ordering of existential and psychological diversity, the regulatory function at its disposal - culture, at the same time, is targeted at the development of individuality, creative uniqueness of each person: "Human diversity has given rise to culture, while culture would enhance that diversity" [13, p.89]. Culture sets psychological characteristics of intersubjective space and produces a decisive influence on the formation of personal meanings that we understand as a meaningful basis for creativity and signification skills. Concurrently, peculiarities and efficiency of creative development depend on which values of structural components of culture and the extent of their internalization are the most significant. Enculturation is understood as the internalization of the values of the kernel structural formation a reference culture.

Within the framework of the semiotic approach, every system (and culture as a system) is analyzed from the perspective of the peculiarities of its semantics, syntax and pragmatics. A study of the semantics of culture involves analysis of its content, the aggregate of meanings, values, moral and aesthetic attitudes; a syntax study - analysis of structural features of culture - its constituent elements and their specific share in the system and peculiarities of their interrelationship. Pragmatic component of semiotic analysis involves investigation of conditions of mutual assistance of culture as a semiotic system and personality. Semiotic approach affords to explore semantics, syntax and pragmatics in their unity to determine the integrity of the system and peculiarities of semiosis (mutual assistance of the systems).

According to the concepts of culture as a system of an ontological level [26], its structural components include religion, ethics, aesthetics and philosophy. They constitute a relatively stable unity, whereupon each component amounts to a subsystem that performs specific functions in the personality development: religion is aimed at creating a common spiritual ideal, aesthetics emotional and evaluative attitudes, ethics behavioral standards, philosophy - world view.

Core structural formation is the "reference culture" that reflects the most important meanings of the national culture - constructive, enshrined in the classical (precedent) texts. The reference culture exercises a function of a "repository" into which people, throughout history, make deposits, retaining the best of it" $[24$, p. 380]. In varying degrees, reflecting 
the values of the reference culture, the cultural environment is filled with subcultures. Besides, certain segments of the culture are filled with inorganic culture - something that emerged in a different national, historical, geographical, mental environment.

Culture transmits its content by means of works of art (V.S.Bibler), texts (Iu.M.Lotman), artifacts (M.Cole). Mediation of human development with those mediators rich in cultural meaning is the condition of one's creative actualization, moving by the "spiritual elevation".

A text is a unit of culture reflecting its systematic properties: "Any text is enclosed in a certain extra-textual structure, the most abstract level of which may be defined as "a type of a world-outlook", a "world view"..." [18, p. 254]. The ratio of the dominant meanings of culture and meanings of each component text is the ratio of truth (in case of conformity) or falsity (in case of counter-propagation). The ratio of truth affords to regard each text incorporated into culture as its systematic component that would update and develop the system, while the falsity ratio - as its destabilization. The texts that are in the truth ratio with culture (reflecting its meanings) are the primary mediators in creative human development. Communication with the texts of the reference culture would provoke personal activity, primarily because these texts appeal to significant spiritual values and are interlocutory by their nature.

Understanding of the reference texts is close to linguistic understanding of the "precedent" textbook classic texts. Yet, verbal works are regarded as precedent texts, while any semiotic object reflecting the values of the reference culture are called the texts of the reference culture.

The reference culture constitutes the most stable part of culture. With varying degrees of completeness, its values are reflected in the mind of every person. S.L.Frank acknowledged that, during the most difficult and devastating times, in the depths of the human soul "there hides a belief in certain absolute values, without which life would lose its meaning, while the spirit, devoid of any support and any arrangement, may only vegetate, but not live and propagate" [30, p. 42]. And the meaning of life, according to research, is the greatest human value [10, p. 11].

Functionally, the reference kernel is not equisignificant with inorganic culture and subcultures. Assertion of the equality of rights of cultural strata and equivalence of cultures is "not so harmless as it may seem at the first glance" [6, p. 270]. The apparent universality of subcultures, their multiplicity would generate in the subject that is internalizing eclectic cultural values and attitudes, an illusion associated with the existence within a culture. An "Orgy of Tolerance" (U. Eco), uncritical acceptance of values antithetic to the reference ones may cause conceptual disorientation, loss of systemic foundation for creative development.

Establishment of a creative personality occurs in culture - a system with its complex syntax, heterogeneous semantics, different pragmatic properties of constituents. Assimilated parts of that environment are unequal for different people. There are variations of the "edge" - the development of the "frontier" areas - subcultures, and options of profound comprehension of the reference culture - its religion, art (aesthetics), ethics and science. The scope of the assimilated environment determines the possibility of free "travel" in there - the more significant cultural stratum was internalized, the more cultural alternatives, options for individual choice of the forms of free behaviour, more opportunities to evaluate probabilistic models of action and creative actualization of one of those are available. The degree of enculturation determines the level of creativity. 
The cultural stratum, the values of which we adopt, is separated from others by a "boundary". The "Boundaries" (Iu.M. Lotman) may block creativity, if they "fence in" a small cultural space when the outreach of the subject is insignificant and, therefore, the potential variability of choice is low. The boundaries would otherwise stimulate creativity - when a huge cultural outreach would create the need for choosing from a variety of semantic variants.

The reference culture is an ontological system, which includes philosophical, aesthetic, ethical, and religious components. Each of them performs an important function in the creative establishment of an individual.

The philosophical component actualizes the processes of 1) development of the system of personal meanings through stimulation of the processes of reflection - awareness of meanings; a work of consciousness directed at the world and the self; 2) development of signification skills, abilities to express semantic structures, their "naming", whereby the subjective is rationalized and objectified, becoming the "common - a fact of culture; 3) expansion of the context of awareness (the connection of new semantic contexts) - posing problematic questions that have no straightforward answers, translation of solutions into a different plane of problems; addressing the "ultimate issues" as a means of enhancing spiritual states and development of personal meanings at a spiritual level.

Importance of the aesthetic component of culture for creative and conceptual development of personality is determined by "the primary function of art - transmission of meanings" (A.N.Leontiev, op. by [17, p. 374]). Perception of the works of art involves activation of artistic experiences and, as a consequence - the dynamics of the system of personal meanings. Rich semantic world is presented in the works of art, its empathic understanding produces a transformative effect on the semantic system of the perceiving subject by way of catharsis.

Literary precedent texts are characterized by staging semantic questions of the spiritual level, while emotional involvement of the perceiving person in the process of their resolution would enhance the process of meaning-making. Understanding of a work of art would activate the processes of formation of signification skills by the way of apprehension of the specifics of an art form and its importance for adequate expression of meanings.

Importance of the ethical component of the educational environment for the development of creativity is associated with the mediation of development of meanings by social communities through the process of value-regulation of behaviour. Ethics as a system of standards governing the manifestation of relationship to another is closely related to the concept of the moral dimension of personal meanings (B.S. Bratus'). Ethical component of interactions implemented by culture, would shape moral principles and signification skills that afford socially adaptive expression of meanings.

Internalization of religious values of culture is associated with the development of semantic sphere of personality through 1) the formulation and solution of problems at the spiritual ("eschatological”) level, 2) dedicated development of reflexive self-awareness (by the way of transmission of concepts of responsibility, guilt, confession and repentance), 3) empowering each act of livelihoods with meaning; 4) enhancement of the processes of meaning-making through enrichment with emotions associated with the experience of one's responsibility and guilt, 5) interlocutory co-existence in faith. V.P.Zinchenko highlights that, without the ideas of a "religious hierarchy", understanding of cultural mediation of human development can not be complete [11]. 
A developing environment is the transmitter of meanings. To understand whether, at the same time, there is a development of creativity, it is important to know, first, the meanings of which structural components of culture the texts are transmitting in the process of semiosis, and, secondly, whether the person understands the "language", the text "talks" to him in, whether he has the signification skills for understanding of the transmitted content and expression of personal meanings.

\section{Development of creativity under} the conditions

\section{of the school educational environment}

The main systemic mediators of cultural development are educational institutions. The importance of cultural benchmarks in the processes of education, the fact that culture should be "the main purpose, the only means, the only possible subject matter" [19, p. 135] for the theory and practice of education, is undeniable. However, a formal description of the methods of initiation "to cultural values" is hopelessly outdated [ibid.] It should be understood, the values of which structural components of culture and in which form are being transmitted by educational environment to predict their developmental effect.

Violation of the principle of dominance of the reference culture while cultivating values of the "popular" culture by means of mass media would help to achieve the goals of "corporate and private owners" - global production of a consumer [24] of material comforts and not the producer of spiritual values. It was no coincidence when V.P.Zinchenko emphasized the need to realign education into the mainstream of solicitous attitude to culture [12].

Educational environment fulfills the function of development. Meanwhile, the "environment" is defined as "a form of existence of the matter representative of its length, structure, coexistence and interaction of elements in all material systems" [29, p. 519]. Use of the definition "environment" as applied to the educational system would thus discharge the function of marking its systemacity and structural complexity.

Following the logic of the semiotic approach, let us consider the educational environment as a secondary semiotic system. Its influence on the development of creativity (personal meaning and signification skills) is determined by structural homomorphism of culture as a modeling system. The type of reflected culture determines the nature of developmental influences. Predictability of the educational environment effect enhancing creativity is determined by its semiotic integrity, when all components of the educational environment transmit meanings of the reference culture.

Amodel of the educational environmentbased on the principle of consistent homomorphism with the reference culture is a semiotically-friendly one: it is targeted, aside from development of creativity, at the moral characteristics of a schoolchild personality. Internalization of ethical, aesthetic, philosophical attitudes is decisive for personal formation.

The educational environment transmits knowledge, moral values, ethical practices, aesthetic perceptions, etc. In the context of the semiotic approach, cultural phenomena are regarded as evidence of communication, and "individual messages are clear and organized in correlation with the code" [33, p. 35], understood by U.Eco as a system of signs in the specifics and unity of its semantics, syntax and pragmatics. The code determines the developmental potential of the developing system.

By virtue of communicative nature of secondary semiotic systems, which include educationalenvironment and theirhomomorphism with systems simulated on their basis, specific 
effects produced by one or another semiotic model of educational environment (EE) on the development of the personality, are predictable. Therefore, the value of semiotics would "radically increase due to the fact that describing codes in terms of a system of expectations valid in the symbolical universe, it would outline corresponding systems of expectations, significant in the universe of psychological phenomena and ways of thinking" [33, p. 38].

Syntactic analysis involves determining structural components of educational environment, the analysis of its semantics - the study of the substantive aspect of the information system to determine the characteristics of the transmitted information - what exactly is the subject of transmission in the process of educational communication, what cultural meanings mediate communication. Pragmatics is understood as a relation between the source that generates information, the information itself and its perceiving subject. As applied to the semiotic system of educational environment, we refer to the nature of relations between the participants of semiosis that determine effectiveness of communication.

Structural EEs are a teacher, a pupil and a didactic text (verbal, visual, musical, etc.). For a system with the mission of cultural reproduction, "one of the functions of a teacher is to be a live semiotic element" [32,p.42]. The semiotic function of a teacher is not only in mediation - adapting educational information to the perception and understanding by the schoolchildren, but in the transmission of cultural attitudes. Schoolchildren in the semiotic model are treated as its less stable components (being in the process of development).

The less is the specific share of the components reflecting the components of the reference culture (its ethical, aesthetic, philosophical and religious concepts) that are compensated by components of subcultures and inorganic cultures in the structure of EE, the more unpredictable is the educational and pedagogic efficiency of interactions determined by the content of educational environment. Culture is the foundation of any particular model of EE, but the nature of reflection of its system components and relationships between them in each specific case has its own peculiarities, which determines the uniqueness of the developmental effect of EE.

Figure 1 shows the general process of interaction of $\mathrm{EE}$ with structural components of culture represented as relatively independent systematic formations. Peculiarities of $\mathrm{EE}$ depend on specific shares of the components of the reference, inorganic and subcultures in its structure. In order for EE to fulfill its function in the development of creativity, components similar to those of the reference culture should predominate in its structure.

Development of a schoolchild personality is, to a great extent, determined by the peculiarities of educational environment, which is explained by the principle of structural homomorphism. However, the developing context is not limited to educational environment of school. Mass media, family, small social groups, a schoolchild belongs to, determine the polysystemic character of developing information connections. Peculiarities of human development depend on structural characteristics of these entities and their specific share in the overall system semiosis.

Educational environment is a semiotic system of an ontological level, constituted of functionally unequal particular systems (structural components) and complex overlapping connections between them. Linguistic and figurative signs (verbal and nonverbal) are used, subject to the laws of that multiple-component system and its internal laws. 


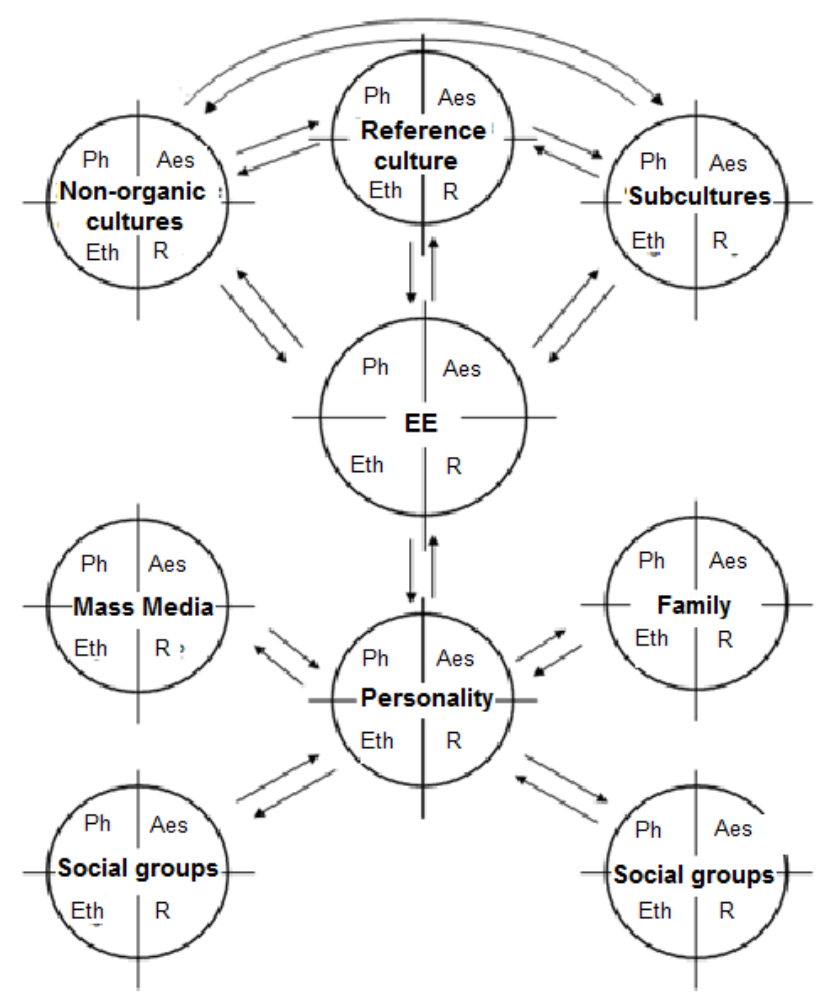

Fig. 1. Effects of the structure of educational environment on the development of a schoolchild personality: EE Educational Environment, R - Religion, Ph - Philosophy, Aes - Aesthetics, Eth - Ethics

Semiotic characteristics of EE influencing the development of creativity personal meaning and signification skills are as follows: 1 ) syntactic: EE structure reflects the structure of the reference culture - its ethics, aesthetics, science and religion; 2) semantic: semiosis is aimed at transmission of the highest levels of meaning, and the higher levels of meaning are transmitted through EE, the stronger is the effect of creativity development; 3) pragmatic: the meaning-making mutual assistance of EE subjects involves not a one-way transmission of information, but a dialogue.

Arrangement of educational environment can be understood as a structuring context of personality development in accordance with the system characteristics of a broader context - the culture. Meanwhile, any unbalancing inside the contextual (modeling) system (misalignment of meanings as semantic characteristics of the system components or syntactic relations between the components, discrepancy between theoretical attitudes and practical communication with schoolchildren, etc.) would cause a process of cultural degradation which, by virtue of consistency between contextual strata, would penetrate from the macro to the micro level. Disturbed balance of EE as a simulated system, derivative in relation to culture: downgrading of certain significant properties (ethical, for example) may cause an imbalance in the system simulated on its basis - an individual. If other educational environments (family, for example) do not perform the function of compensating, then the imbalance in the EE system would reflect in the misbalance of a personal system: development of one significant quality may combine with underdevelopment of another (e.g., high creativity (understood as originality) and low moral level). 
The value of integrity in the developmental context for the development of personality was emphasized by L.S. Vygotsky. Arrangement of educational environment is an organization "of not only the main occupation, which is now entrusted to the pupil, but all incidental circumstances: situation, provisions and clothing of a schoolchild, the kind of view opening from his/her window... One of the writers said that for the Russian person everything depends on the situation, he/she cannot fail to be a villain in a tavern and prove totally incapable of meanness in the middle of solid and austere architecture" [5, p. 127].

Cultural context defines the characteristics of educational environment. V.P.Zinchenko, analyzing educational systems that have generated great personalities, says that such education was reproducing culture - it was primarily transmitting "a global view of the world, filled not only with objects of scientific thought, not only examples of moral behaviour, but also with human values. Education was aimed to recreate the environment, nutritious and nourishing for personality, which is culture" [11, p. 266].

Developing context determined by mass media today is not targeted to transfer the content of the reference culture. Values and samples of "stellar" (ideal) behaviour reflect the attitudes of inorganic cultures and popular subculture. School EE, under such conditions, should fulfill the function of compensation, especially since the share of another important educational institution - the family - is declining in the total developing environment.

Teaching pupils "to read the meanings" from the texts of the reference culture is available only to those who themselves are "able to read". The requirement for a high level of culture of a teacher is both obvious and, with each passing day, the more difficult to fulfill for both economic reasons and those associated with the context of development of educators themselves. Therefore, modeling school EE reflecting the structure of the reference culture requires special training of future psychologists and educators.

Now, we will consider culture in its capacity of the original and the largest generating model. Its structure constitutes a kernel - a reference culture, as well as subcultures and inorganic cultures. The generated model of educational environment may reflect that structure with offset keynotes - an increased share of components of certain subcultures or inorganic cultures in the system. By virtue of importance of the reference culture for personal development, the circumstance that it is reflective of existential, spiritual meanings most significant for creative development and determines the possibility of transcendence, we may assert that the dominance of the structural kernel - the reference culture in the simulated EE system, allows to achieve the goal of development of schoolchildren creativity.

An important structural feature of the described model of educational environment is the relationship of homomorphism with the reference culture of each semiotic element: a didactic text, teachers, schoolchildren. In other words, the text as an element of semiosis should reflect ethical, aesthetic, world-outlook, religious attitudes of the reference culture. A teacher, in the educational environment for developing creativity, is a representative not of the popular, but the reference culture - a "semiotic element" transmitting its meanings. A schoolchild (as a semiotic system), by virtue of propensity of the macro system of educational environment towards equilibrium in the process of semiosis, is committed to appropriation of attributes of similarity with the systems of the text and the teacher - a reflection of their structure with a characteristic interposition of components, their specific shares and a keynote. 
A teacher transmits meanings through his/ her image, which is understood as a system of mediation between the semiotic systems of a teacher and a schoolchild.

The provision relevant to the modeling of educational environment is semantic commitment of the system components. The reference culture as a basis of the model under consideration contains attitudes of different world-outlook semantic levels: domestic, social, national, cultural and spiritual [28]. Then, the derivative model can reflect them in varying degrees, for example, be biased predominantly towards the social level. Systematic domineering of the higher - spiritual level of meaning - is necessary for the development of creation. Priority ranking of that level in the structure of personality stipulates actualization of creativity.

The values of the reference culture are: 1) transmitted during scheduled school lessons (invariant), 2) labeled in the variable part of the curriculum, 3) implemented during the extracurricular activities; 4) all the interaction of educational process subjects is subordinated to the structural laws of the reference culture: its component semantics is represented by the images of teachers, stylistics of extracurricular activities, the manner of communication with parents, etc.

The philosophical component of the EE structure is primarily labeled at the lessons of literature and history, at drama lessons and, in varying degrees - all others. The same syntactic distribution applies to the religious component: all domestic culture is essentially Orthodox its attitudes are marked in the reference texts that schoolchildren operate with during their literature, history, local studies, culture of speech classes, during drama lessons.

Modeling of educational environment thus involves participation of all organizational substructures of EE in the transmission of semantics of the reference culture. We hence proceed from the concept of psychological inexpediency of cultural eclecticism representation, in a classroom and during extracurricular activities, of the structure of the culture (with priority of subcultural or inorganic components) which reflects the value system of a teacher, irrespective of the semantic dominant of the reference culture, characterized by randomness that stipulates unpredictability of the effects on the development of meanings. In a traditional educational environment, cultural integrity of EE is not regulated.

In an educational system, share of components considered in their connection with the cultural system, varies. The most comprehensive are religious values. Substantial preconception of philosophical (world-outlook), ethical (moral) and aesthetic elements of the structure is determined with their involvement in educational environment. It was no coincidence when L.S.Vygotsky emphasized the need to strengthen ethical and aesthetic components in the post-revolutionary period of downgraded religious values for the purpose of their compensation [5]. In a secular school, philosophy (ideally) becomes the backbone, kernel factor of the system. Worldview attitudes would, in their turn, determine ethical, aesthetic and scientific priorities. In case of incomplete formation of a world-outlook, ethics may play strategic role being, in that particular case, a set of moral standards. Thereafter, the structure may be reduced to the aesthetic and scientific, or (worst case) scientific only (didactic) component, which reduces the effectiveness of $\mathrm{EE}$ for development.

Figure 2 shows the organization of mutual assistance of subjective components of the EE structure. In the process of a dialogue, development of a schoolchild personality as a system component, occurs. Functional "equality" 


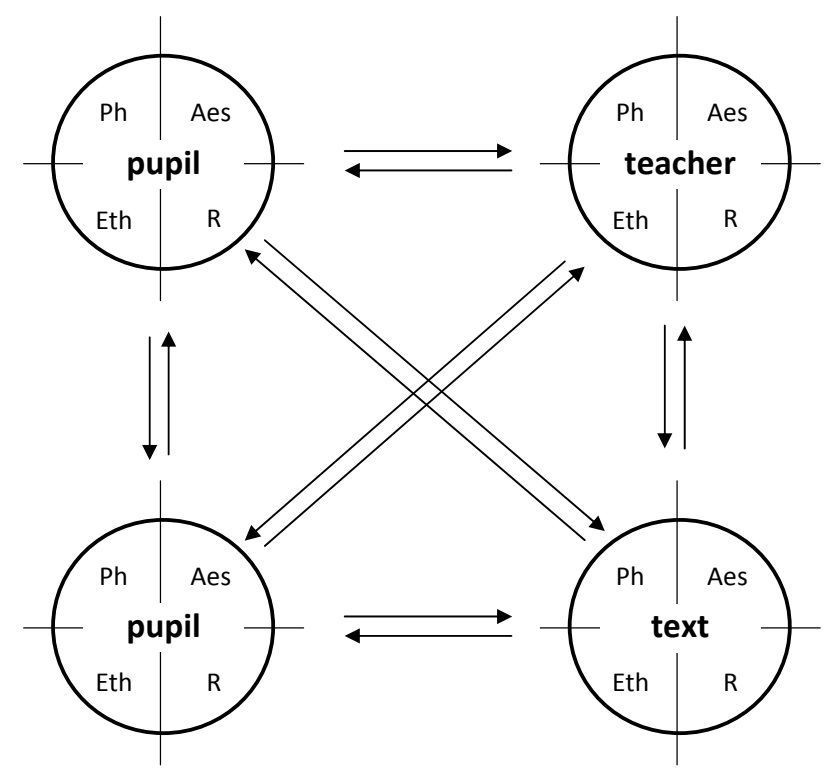

Fig. 2. Pragmatic characteristic of EE. Note: R - Religion, Aes - Aesthetics, E - Ethics, Ph - Philosophy

of components is secured by mutual assistance of "I-Thou" (M.Buber). It provides for an activation of the semiotic system of each participant of semiosis, a tension of its semantic membranes.

A meaning-making dialogue as a pragmatic characteristic of EE is secured not only by mutual assistance of components, but also systemic features of each of them. What it involves is, first, semiotic structure (as substructure) of components: the ratio of specific shares of a reference culture, an inorganic culture and a subculture in each of them (and, consequently, the degree of initial harmony between the systems of a teacher, a text, and a pupil) and, second, the adequacy of their symbolic representation that secures adequate understanding.

The presented EE model assumes implementation by all EE components at every school lesson and during extracurricular interaction. The technology of formation of creativity developed on the basis of the model is aimed at securing conditions for meaning-making dialogue of subjective components of educational environment. At a literature class, the mechanism of its implementation may be represented as follows:

1. Creating conditions for adequate perception of a literary text: minimization of external and internal distractions through the rational arrangement of physical space (in particular, schoolchildren share the same table or sit on mats in a circle) and easy relaxation.

\section{Listening (reading) text.}

3. Actualization of the perceived content (code conversion) by each participant of the educational process in their individually elected format (describe their impressions in the format of text or associations, or outline in a sketch or movements).

4. Discussion of resulting texts reflecting individually assimilated meanings of the perceived (in the form of a dialogue). Discussion assumes acceptance of each of the generated texts - there are no "wrong ones".

5. Objective analysis of the text immediately following results obtained in the course of discussing the findings. At this stage, there 
occurs training in interpretation of a literary text - training of signification skills (methods of creation of a literary form).

In the course of such lessons, actualization of the perceived (stage 3 ) becomes more adequate to both peculiarities of personal meaning, which are endowed to the perceived text by a pupil, and objective semantic content of the work.

The presented model of educational environment had been implemented in the course of a seven-year experiment at a school in Irkutsk. Analysis of the results showed that the dynamics of creativity among the participants of the experiment was significantly higher than that 1) in the control group of schoolchildren studying in regular classes, 2) in a group of schoolchildren studying in classes with indepth study of the humanities, and 3) a group of schoolchildren studying under the conditions of implementation of the model of development of creativity based on the principles of humanistic psychology. That afforded to accept the judgment that enculturation is a universal principle of the creativity development and a productive base for organization of educational environment at school as verified.

\section{References}

1. Bakhtin M.M. Aesthetics of Verbal Creativity. M.M.Bakhtin. M.: Prosveshchenie, 1979. P. 176.

2. Bogoiavlenskaia D. B. Psychology of Creative Abilities. D.B.Bogoiavlenskaia. M.: Academia, 2002. P. 320

3. E. de Bono. Lateral Thinking. Edward de Bono. SPb.: Piter Publishing, 1997. P. 320

4. Bratus' B.S. Personal Meanings Following A.N. Leontiev and the Problem of Consciousness Vertical Line. Traditions and Prospects of Activity Approach in Psychology. School of A.N. Leontiev. A.G. Asmolov, Y.D.Babaev, N.B.Berezanskaia, et al. M., 1999. Pp. 284-298.

5. Didenko V. D. Spiritual Reality and Art: Aesthetics of Transfiguration. M.: Belovodie 2005. P. 288

6. Druzhinin V. N. Psychology of General Capabilities. M.; SPb.: Piter, 1999. P. 368

7. Druzhinin V. N. Life Options: Essays of Existential Psychology. M.: PER SE; SPb.: IMATON-M, 2000. P. 135

8. Druzhinin V. N. Cognitive Abilities: Structure, Diagnostics, Development. M.: PER SE, SPb.: IMATON-M, 2001. P. 224

9. Eco U. Absent Structure: an Introduction to Semiology. SPb.: Symposium, 2004. P. 544

10. Encyclopedic Dictionary of Philosophy / ed. Averintsev et. al. M.: Sovetskaia Entsyklopediia, 1989

11. Feldman Ia. A. Theory of Levels and a Human Model. M.: Dobroe slovo, 2005. P. 224

12. Frank S. The Unread...: Articles, Letters, Memoirs. M.: Moscow School of Political Research, 2001. P. 592

13. Guilford J. P. Creativity. American Psychologist. No. 5. Pp. 444-454.

14. Herskovits M. J. Man and his works: the science of cultural anthropology. New York: A.A. Knopf, 1948. - XVIII, 678, XXXVII p. ill., maps.

15. Kholodnaia M.A. Psychology of Intelligence. Paradoxes of Research. Spb: Piter, 2002. P. 272.

16. Kravchenko A. I. Cultural Studies. M.: Acad. Project, 2001. p. 340

$$
-2122 \text { - }
$$


17. Cultural Studies]/ ed. G.V. Drach. Rostov-on-Don: Phoenix, 2004. p. 576

18. Kyshtymova I. M. Psycho-Semiotic Method of Diagnostics of Verbal Creativeness. Psychological Journal. 2008. Vol. 29. No. 6. Pp. $56-67$.

19. Leon'tiev D.A. Psychology of Meaning: Nature, Structure and Dynamics of Conceptual Reality. M.: Smysl, 1999. P. 487.

20. Lotman Iu.M. Structure of Literary Text. On Art: Articles. Notes. Public Speeches. (19671998) / Iu. M. Lotman. SPb., 1998. Pp. 14-277.

21. Mae R. he Courage to Create: Essay on Psychology of Creation. Lvov: Initsiativa, M.: Institute of General Humanitarian Studies, 2001. P. 128.

22. Mikhailov F.T. Creative Ability of Self-Awareness. Selections. M.: Indrik, 2001. Pp. 233244.

23. Nalimov V.V., Drogalina Zh. A. Reality of the Unreal. M.: A World of Ideas, 1995. P. 431.

24. Ozhiganova G.V. Method of Diagnosis and Shaping of Creativity in Children of Primary School Age. M.: IP RAN, 2005. P. 135.

25. Ponomarev Ia.A. Psychology of Creation. Trends in the Development of Psychological Science. Exec. Ed. B.F. Lomov, L.I. Antsyferova. M., 1989. P. 21-35.

26. Rubinstein S.L. Being and Consciousness. Man and the World. SPb.: Piter, 2003. P. 512.

27. Seravin A. I. Research of Creation. SPb.: Kopy-Park, 2005. P. 205.

28. Shchedrovitsky G.P. The Method of Semiotic Study of Sign Systems. Semiotics and Oriental Languages: Collected Works. Exec. Ed. Iu.V.Rozhdestvensky. M., 1967. Pp. 19-47.

29. Solomonik A. Positive Semiotics: (about Signs, Sign Systems and Semiotic Activity. Minsk: MET , 2004. P. 191.

30. Sternberg R., Grigorenko E. Learn to Think Creatively. Basic Modern Concepts of Creativity and Giftedness: Collective Works / ed. D.B. Bogoiavlenskaia. M.: Molodaia Gvardiia, 1997. Pp. 186 213.

31. Vygotsky L.S. Educational Psychology. M.: Pedagogika-Press, 1996. P. 536.

32. Zhuravlev A. L., Iurevich A.V. Collective Meanings as Prerequisites for Personal Happiness. Psychological Journal. 2014. Vol. 35. No. 1. Pp. 5-15.

33. Zinchenko V.P., Morgunov E.B. A Developing Person: Essays on Russian Psychology. M.: Trivola, 1994. P. 304.

34. Zinchenko V.P. Staff of Osip Mandelstam and Pipe of Mamardashvili: To the Origin of Organic Psychology. M.: Novaia Shkola, 1997. P. 336.

35. Zinchenko V.P. Very Subjective Notes about Psychological Diagnosis. Chelovek. 2001. № 1. Pp. 87-93. 


\section{Развитие креативности школьников \\ в процессе инкультурации}

\section{И.М. Кыштымова}

Иркутский государственный университет Россия, 664003, Иркутск, ул. Карла Маркса, 1

В статье аргументирован тезис о продуктивности инкультурации для развития креативности школьников. Обозначень основные представления о творчестве и креативности, маркированы их противоречия. Предложен подход к пониманию и развитию креативности, основанием которого являются представления психосемиотики, культурноисторической и экзистенциальной психологии. Показано, что креативность представляет собой свойство личности, проявляющееся в реализации личностного смысла средствами культуры. Охарактеризованы оба компонента креативности. Показано, что развитие креативности связано со смысловой динамикой и формированием сигнификационных умений выражения смысла средствами знаковых систем.

Обосновано представление об образовательном пространстве как системе, находящейся в отнотениях гомоморфизма с культурой как базовой системой и личностью. Показана зависимость смыслового развития школьника от того, иенности каких структурных компонентов культуры транслирует образовательное пространство.

Описана онтологическая структура культуры. Представлено значение ее ядерного образования - камертонной культуры, которая транслирует смыслы посредством прецедентных текстов. Раскрыта роль камертонной культуры в процессах развития креативности. Высказано суждение, что культурная эклектика, когда в образовательном пространстве транслируются ценности разных структурных компонентов структуры, обусловливает непредсказуемость развивающего эффекта.

Раскрыто содержание понятия «инкультурация». Показано, что она составляет основу механизма развития креативности. Описана психосемиотическая модель образовательного пространства школы, направленного на развитие креативности школьников.

Ключевые слова: инкультураиия, креативность икольников, психосемиотическая модель образовательного пространства школьл.

Научная специальность: 13.00.00 - педагогические науки, 19.00.00-nсихологические науки. 